\title{
Association between agenesis and root morphology of anterior teeth
}

\author{
Associação entre agenesia e a morfologia radicular de dentes anteriores

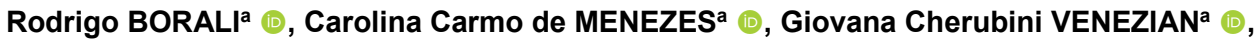 \\ Silvia Amélia Scudeler VEDOVELLO ${ }^{a} \mathbb{0}$, Viviane Veroni DEGAN ${ }^{\mathrm{a} *} \mathbb{( 1 )}$ \\ aFHO - Fundação Hermínio Ometto, Departamento de Ortodontia, Araras, SP, Brasil
}

\begin{abstract}
How to cite: Borali R, Menezes CC, Venezian GC, Vedovello SAS, Degan VV. Association between agenesis and root morphology of anterior teeth. Rev Odontol UNESP. 2019;48:e20190091. https://doi.org/10.1590/1807-2577.09119
\end{abstract}

\begin{abstract}
Resumo
Introdução: A agenesia dentária pode afetar a raiz radicular e deve ser considerada no tratamento ortodôntico. Objetivo: 0 objetivo deste estudo foi avaliar a associação entre agenesia dentária e a morfologia radicular dos dentes anteriores. Material e método: Foram avaliadas em 102 radiografias periapicais dos dentes anteriores de 51 indivíduos divididos em 3 grupos: Grupo $1(\mathrm{n}=16)$ sem agenesia dentária; Grupo 2 ( $\mathrm{n}=17$ ) com agenesia dentária de terceiros molares; Grupo 3 ( $\mathrm{n}=18$ ) com agenesia dentária apenas de prés-molares ou incisivos laterais. A morfologia radicular dos dentes anteriores foi avaliada sendo classificada como raiz curta, abaulada, tortuosa e pipeta. Para a comparação do formato radicular foi utilizado o teste Exato de Fisher, para a distribuição dos sexos entre os grupos foi realizado o teste qui-quadrado e para comparar as idades entre os grupos foi realizada o teste ANOVA, todas as análises com nível de significância de 5\%. Resultado: Os resultados evidenciaram diferença significante nos formatos das raízes $(\mathrm{P}<0,05)$ entre os grupos com e sem agenesia. 0 formato radicular abaulado foi o mais prevalente em todos os grupos, aparecendo em maior número no grupo 3 (84,3\%). Conclusão: Conclui-se que houve associação entre agenesia dentária e a morfologia radicular dos dentes anteriores.
\end{abstract}

Descritores: Ortodontia; agenesia dentária; ápice dentário; raiz dentária.

\begin{abstract}
Introduction: Tooth agenesis is likely to affect the root teeth and should be considerated in orthodontic tratament. Objective: The aim of this study was to assess the association between agenesis and root morphology of anterior teeth. Material and method: The anterior teeth of 51 individuals were evaluated on 102 periapical radiographs and then divided into three groups: Group $1(n=16)$ - no tooth agenesis; Group 2 ( $n=17)$ - only third molar agenesis; and Group $3(n=18)$ - tooth agenesis of premolars or lateral incisors. Root morphology of anterior teeth was evaluated and the roots were classified as short, blunt, apically bent, and pipette-shaped. Fisher's exact test was used to compare root shapes, the chi-square test was used to obtain the distribution of sexes between the groups, and ANOVA was performed to compare the ages between the groups. The significance level was set at $5 \%$ for all analyses. Result: There was significant difference in root shapes $(\mathrm{P}<0.05)$ between the groups. Blunt roots were the most prevalent in all groups, but their rate was higher in Group 3 (83\%). Conclusion: There was association between agenesis and root morphology of anterior teeth.
\end{abstract}

Descriptors: Orthodontic; tooth agenesis; tooth apex; tooth root.

\section{INTRODUCTION}

Tooth agenesis is complex, and its heterogeneous characteristics are apparently associated with other dental changes ${ }^{1}$. The etiology of tooth agenesis involves mutations in certain genes such as MSX1 and PAX9, and genes such as WNT10A appear to play an important role in odontogenesis ${ }^{2-4}$. 
Tooth agenesis is likely to affect other teeth in the same individual and has also been associated with various other dental changes, such as microdontia, differences in tooth calcification and eruption, reduction in size and change in crown shape of the remaining teeth ${ }^{5-16}$.

The orthodontic treatment of patients with agenesis entails the risk of severe resorption, particularly in cases with changes in root shape, long-term orthodontic treatment, and use of intermaxillary elastic traction ${ }^{17-21}$.

Root resorption is linked to root morphology ${ }^{19}$, but the risk of severe resorption is greater in some roots, such as in pipette-shaped ones ${ }^{19}$. Published studies have tended to relate resorption directly to agenesis ${ }^{17,19}$ or to root shape ${ }^{18,22,23}$, but studies assessing whether there is a direct relationship between agenesis and root morphology are still lacking.

Thus, the aim of this study was to evaluate the association between the root morphology of anterior teeth and tooth agenesis.

\section{MATERIAL AND METHOD}

This cross-sectional study was approved by the local Research Ethics Committee (process no. 58297616.4/0000.5385).

The sample size was calculated based on data obtained from a pilot study, considering a $95 \%$ confidence interval, a $5 \%$ sample error, a $5 \%$ significance level, and an $80 \%$ power. A total of 384 roots of upper and lower incisors were then required, corresponding to 48 individuals, of whom 96 periapical radiographs were evaluated.

The sample was composed of 102 periapical radiographs of 51 individuals taken using the paralleling technique and obtained from the charts of patients referred for orthodontic treatment at a private dental office. The selection criteria were as follows: male and female individuals, eruption of all permanent teeth up to the first molars, absence of supernumerary teeth, no previous orthodontic treatment, no permanent tooth losses, and no severe anterior tooth crowding.

The sample were divided into three groups, as follows:

a) Group 1 (no tooth agenesis) - composed of 32 periapical radiographs of 16 individuals ( 8 males and 8 females) with a mean age of 20.6 years (range of 13.1 to 38.1 years);

b) Group 2 (agenesis of third molars or of other teeth) - composed of 34 periapical radiographs of 17 individuals ( 5 males and 12 females) with a mean age of 18.6 years (range of 11.1 to 33.4 years);

c) Group 3 (agenesis of premolars and lateral incisors and no third molar agenesis) - composed of 36 periapical radiographs of 18 individuals ( 6 males and 12 females) with a mean age of 17.8 years (range of 12.8 to 35.2 years).

The allocation described above was used to minimize the possible action of various genes in individuals with agenesis of third molars and other dental groups, which could potentiate or mix the phenotypic expression of root shape, thus making it impossible to identify a specific characteristic of root shape $\mathrm{e}^{2,3,10}$.

Periapical radiographs were used to evaluate the root morphology of anterior teeth. All the radiographs were of the same radiological center, to maintain the same image resolution and were selected in the interval of 3 years, which allowed a better evaluation of the radicular shape. The radiographs were digitized using Soredex DIGORA Optime scanner, providing the same sensitivity as that of conventional films ${ }^{18}$, and were analyzed in a darkroom using Adobe Photoshop Express. 
Root shapes were evaluated and classified by the main author according to their geometry into short, blunt, apically bent, and pipette-shaped. Short roots (A) are those whose length is smaller than the crown length ${ }^{24}$. In this study, a root was considered to be short when the root-crown ratio was smaller than 2:1 when compared to length. Blunt roots (B) were those with a more regular shape without large deviations along their root axis or without root apex elongation. Apically bent roots (C) are those with some deviation on their axis and a change in apical direction. Pipette-shaped roots (D) are those with some sharp elongation at the root third (Figure 1).

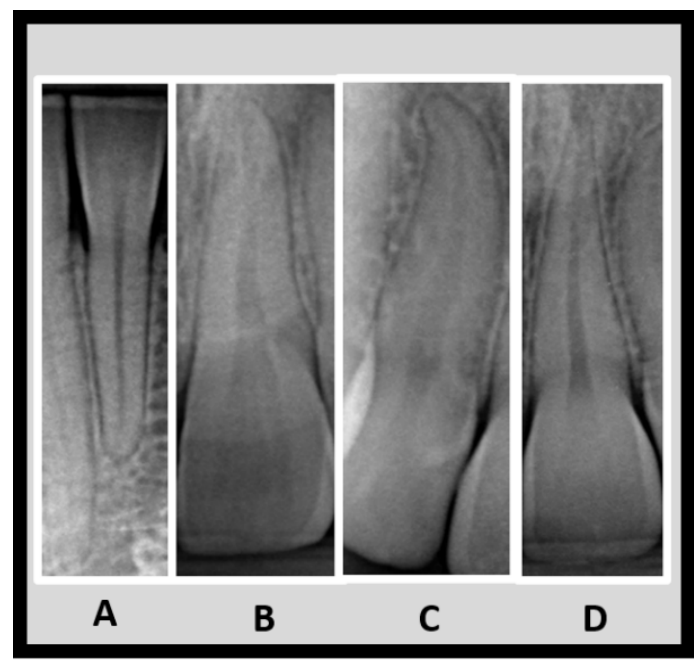

Figure 1. Geometric shape of the roots: short (A), blunt (B), apically bent (C), pipette-shaped (D).

For intra-examiner calibration, 72 roots of upper or lower incisors were evaluated and measured again by the same examiner after a 30-day interval. Reproducibility of the evaluation of root shapes was excellent according to the Kappa coefficient (0.921).

\section{Statistical Analysis}

The groups were initially compared in terms of age (ANOVA) and sex (chi-square test). Association between the presence of agenesis and root shape was analyzed by Fisher's exact test. All analyses were performed using the SAS statistical program ${ }^{25}$, at a $5 \%$ significance level.

\section{RESULT}

There were no statistically significant differences in age between the groups $(\mathrm{p}=0.5210)$, as shown in Table 1.

Table 1. Mean age (standard deviation) of the sample according to group

\begin{tabular}{ccc}
\hline Group & $\mathbf{N}$ & Mean (standard deviation) \\
\hline 1 & 16 & $20.6(8.1)$ \\
2 & 17 & $18.6(6.7)$ \\
3 & 18 & $17.8(6.6)$ \\
\hline
\end{tabular}

$\mathrm{p}=0.5210 . \mathrm{N}=$ sample size.

No significant difference was observed in the distribution of sexes between the groups $(\mathrm{p}=0.4320)$ (Table 2$)$. 
Table 2. Frequency distribution of sexes according to groups

\begin{tabular}{|c|c|c|c|}
\hline \multirow{3}{*}{ Group } & \multicolumn{2}{|c|}{ Sex } & \multirow{2}{*}{ Total } \\
\hline & Male & Female & \\
\hline & \multicolumn{2}{|c|}{$N(\%)$} & $\mathrm{N}(\%)$ \\
\hline 1 & $8(42.1)$ & $8(25.0)$ & $16(31.4)$ \\
\hline 2 & 5 (26.3) & $12(37.5)$ & $17(33.3)$ \\
\hline 3 & $6(31.6)$ & $12(37.5)$ & $18(35.3)$ \\
\hline Total & $19(100.0)$ & $32(100.0)$ & $51(100.0)$ \\
\hline
\end{tabular}

$\mathrm{p}=0.4322 . \mathrm{N}=$ sample size.

There was significant association between root shape and group $(\mathrm{p}<0.0001)$, as presented in Table 3. Blunt roots were the most frequent ones. Group 1 presented a higher frequency of pipette-shaped roots than did the other groups (27.3\%). Group 2 was the only one with short roots (1.5\%). Group 3 had a larger rate of blunt roots than did the other groups (84.3\%) and a lower frequency of apically bent roots $(6.0 \%)$.

Table 3. Frequency distribution of root shapes according to groups

\begin{tabular}{|c|c|c|c|c|c|}
\hline \multirow{3}{*}{ Group } & \multicolumn{4}{|c|}{ Root shape } & \multirow{2}{*}{ Total } \\
\hline & Short & Blunt & Bent & Pipette & \\
\hline & \multicolumn{4}{|c|}{$N(\%)$} & $N(\%)$ \\
\hline 1 & $0(0.0)$ & $71(55.5)$ & $22(17.2)$ & 35 (27.3) & $128(100.0)$ \\
\hline $2^{*}$ & $2(1.5)$ & 93 (69.9) & 27 (20.3) & 11 (8.3) & $133(100.0)$ \\
\hline $3^{*}$ & $0(0.0)$ & $113(84.3)$ & $8(6.0)$ & $13(9.7)$ & $134(100.0)$ \\
\hline
\end{tabular}

$\mathrm{p}<0.0001 . \mathrm{N}=$ sample size. ${ }^{*}$ Different from Group 1.

\section{DISCUSSION}

Studies comparing individuals with and without third molar agenesis clearly show that those with third molar agenesis have a smaller crown size and greater chance of agenesis in another tooth ${ }^{10,11}$. However, even in individuals without third molar agenesis, agenesis of premolars and lateral incisors was significant. This was the reason why the authors of the present study chose to allocate individuals with third molar agenesis and those with agenesis of premolars and lateral incisors to different groups.

Evaluation of root shape of upper and lower incisors in this study demonstrated that individuals with third molar agenesis and those with agenesis of premolars or lateral incisors had different root morphology for upper and lower incisors from those individuals without tooth agenesis. These findings are at odds with those of a previous study where, after evaluation of root resorption of lateral incisors, there was no apparent association between root shape and genetic factors, even though the evaluation of root shape was not within the scope of the study 22 and considering that tooth agenesis has a genetic etiology ${ }^{2-4}$.

It may be suggested that different genetic mutations caused changes in phenotypic expression of the root morphology of incisor teeth in individuals with and without tooth agenesis, thus following a trend, as pointed out in previous studies that assessed crown size, number of teeth, and crown shape ${ }^{10,11}$. It is, however, important to underscore that the difference in the root morphology of upper and lower incisors between Groups 2 and 3 was not within the scope of the present study.

Root morphology of anterior teeth with triangular, dilacerated, and pipette-shaped roots shows a greater predilection for severe root resorption ${ }^{18,19,26}$. This study evidenced that individuals with agenesis did not show root shapes of upper and lower incisors that posed greater risk for severe resorption, as occurs in teeth with triangular, pipette-shaped, and apically bent 
roots. This finding seems to be consistent with other studies that could not find a higher prevalence of root resorption among individuals with tooth agenesis ${ }^{23,26}$.

Not only the root shape of upper and lower incisors could increase root resorption, but also other factors such as length of orthodontic treatment, use of intermaxillary elastic traction, amount of root apex movement as a result of the torque of rectangular wires, type of orthodontic technique used, tooth intrusion and extrusion, and orthodontic treatments with tooth retractions for extraction space closure and diastemas 18,19 . Therefore, individuals with tooth agenesis, especially in premolars and lateral incisors, may have higher root resorption in anterior teeth during orthodontic treatment even when upper and lower incisors do not have root shapes that pose some risk of resorption, owing to the fact that these individuals often have malocclusion with diastemas in the dental arch and unfavorable tooth inclinations caused by agenesis of premolars or lateral incisors, requiring more complex orthodontic treatments, orthodontic mechanotherapy with larger tooth movements across rectangular wires, use of elastic traction, and prolonged orthodontic treatment ${ }^{19}$.

Incisors are the teeth most widely affected by root resorption ${ }^{18}$, and several studies have shown that individuals with agenesis of upper lateral incisors, premolars, and third molars are more likely to have impacted canines in the palate and upper lateral incisors or conoid upper lateral incisors with smaller crown size $e^{9,11,13}$, which may lead to clinical complications and the need for orthodontic mechanotherapy ${ }^{19}$. In this case, it is reasonable to expect larger root resorption in conoid lateral incisors. However, conoid lateral incisors or smaller lateral incisors have not demonstrated a higher probability of increased root resorption when compared with normal lateral incisors ${ }^{23}$. The fact that conoid lateral incisors are more common in individuals with tooth agenesis might have contributed to reducing the risk inherent to the root shape, counteracting the effect of root resorption, even when these teeth are subjected to more vigorous orthodontic mechanotherapy.

This study highlighted the difference in root shape between individuals with and without tooth agenesis, especially in those with agenesis of premolars or lateral incisors, in which the blunt shape was more prevalent, whereas roots with large dilacerations or root elongation were less frequent. Thus, apparently, if agenesis occurs more anteriorly, there is a tendency towards a round root shape with fewer deviations or elongation of the root apex. By comparing roots and crowns, this finding seems to corroborate studies ${ }^{11,13}$ where the further anterior the agenesis, as in the case of premolars or lateral incisors, the smaller the size and shape of tooth crowns.

A limitation of this study was the failure to identify genetic mutations in the assessed individuals.

\section{CONCLUSION}

There was association between tooth agenesis and the root morphology of anterior teeth.

\section{REFERENCES}

1. Kolenc-Fusé FJ. Agenesias dentarias: en busca de las alteraciones genéticas responsables de la falta de desarrollo. Med Oral Patol Oral Cir Bucal. 2004 Dic;9(5):385-95. PMid:15580115.

2. Vastardis H. The genetics of human tooth agenesis: new discoveries for understanding dental anomalies. Am J Orthod Dentofacial Orthop. 2000 Jun;117(6):650-6.

http://dx.doi.org/10.1016/S0889-5406(00)70173-9. PMid:10842107.

3. Tallón-Walton V, Manzanares-Céspedes MC, Carvalho-Lobato P, Valdivia-Gandur I, Arte S, Nieminen P. Exclusion of PAX9 and MSX1 mutation in six families affected by tooth agenesis: a genetic study and 
literature review. Med Oral Patol Oral Cir Bucal. 2014 May;19(3):e248-54.

http://dx.doi.org/10.4317/medoral.19173. PMid:24316698.

4. Ceyhan D, Kirzioglu Z, Calapoglu NS. Mutations in the MSX1 gene in Turkish children with nonsyndromic tooth agenesis and other dental anomalies. Indian J Dent. 2014 Oct;5(4):172-82. http://dx.doi.org/10.4103/0975-962X.144717. PMid:25565750.

5. Al-Abdallah M, AlHadidi A, Hammad M, Al-Ahmad H, Saleh R. Prevalence and distribution of dental anomalies: a comparison between maxillary and mandibular tooth agenesis. Am J Orthod Dentofacial Orthop. 2015 Nov;148(5):793-8. http://dx.doi.org/10.1016/j.ajodo.2015.05.024. PMid:26522039.

6. Antonarakis GS, Suri S. Prevalence and patterns of permanent tooth agenesis in patients with nonsyndromic Pierre Robin sequence. Am J Orthod Dentofacial Orthop. 2014 Apr;145(4):452-60. http://dx.doi.org/10.1016/j.ajodo.2013.11.021. PMid:24703283.

7. Yaqoob O, DiBiase AT, Garvey T, Fleming PS. Relationship between bilateral congenital absence of maxillary lateral incisors and anterior tooth width. Am J Orthod Dentofacial Orthop. 2011 Mar;139(3):e229-33. http://dx.doi.org/10.1016/j.ajodo.2010.04.030. PMid:21392666.

8. Ruiz-Mealin EV, Parekh S, Jones SP, Moles DR, Gill DS. Radiographic study of delayed tooth development in patients with dental agenesis. Am J Orthod Dentofacial Orthop. 2012 Mar;141(3):30714. http://dx.doi.org/10.1016/j.ajodo.2011.08.026. PMid:22381491.

9. Hua F, He H, Ngan P, Bouzid W. Prevalence of peg-shaped maxillary permanent lateral incisors: a metaanalysis. Am J Orthod Dentofacial Orthop. 2013 Jul;144(1):97-109. http://dx.doi.org/10.1016/j.ajodo.2013.02.025. PMid:23810051.

10. Garn SM, Lewis AB. The relationship between third molar agenesis and reduction in tooth number. Angle Orthod. 1962 Jan;32(1):14-8.

11. Garn SM, Lewis AB. The gradient and the pattern of crown-size reduction in simple hypodontia. Angle Orthod. 1970 Jan;40(1):51-8. PMid:5262688.

12. Brook AH. A unifying aetiological explanation for anomalies of human tooth number and size. Arch Oral Biol. 1984;29(5):373-8. http://dx.doi.org/10.1016/0003-9969(84)90163-8. PMid:6611147.

13. Garib DG, Peck S, Gomes SC. Increased occurrence of dental anomalies associated with secondpremolar agenesis. Angle Orthod. 2009 May;79(3):436-41. http://dx.doi.org/10.2319/00033219(2009)079[0436:IOODAA]2.0.CO;2. PMid:19413376.

14. Garib DG, Alencar BM, Ferreira FV, Ozawa TO. Anomalias dentárias associadas: o ortodontista decodificando a genética que rege os distúrbios de desenvolvimento dentário. Dental Press J Orthod. 2010;15(2):138-57. http://dx.doi.org/10.1590/S2176-94512010000200017.

15. Nuvvula S, Kiranmayi M, Shilpa G, Nirmala SV. Hypohyperdontia: Agenesis of three third molars and mandibular centrals associated with midline supernumerary tooth in mandible. Contemp Clin Dent. 2010 Jul;1(3):136-41. http://dx.doi.org/10.4103/0976-237X.72775. PMid:22114403.

16. Vucic S, Dhamo B, Kuijpers MA, Jaddoe VW, Hofman A, Wolvius EB, et al. Craniofacial characteristics of children with mild hypodontia. Am J Orthod Dentofacial Orthop. 2016 Oct;150(4):611-9. http://dx.doi.org/10.1016/j.ajodo.2016.03.021. PMid:27692418.

17. Kjaer I. Morphological characteristics of dentitions developing excessive root resorption during orthodontic treatment. Eur J Orthod. 1995 Feb;17(1):25-34. http://dx.doi.org/10.1093/ejo/17.1.25. PMid:7737342.

18. Levander E, Malmgren O. Evaluation of the risk of root resorption during orthodontic treatment: a study of upper incisors. Eur J Orthod. 1988 Feb;10(1):30-8. http://dx.doi.org/10.1093/ejo/10.1.30. PMid:3162877.

19. Levander E, Malmgren O, Stenback K. Apical root resorption during orthodontic treatment of patients with multiple aplasia: a study of maxillary incisors. Eur J Orthod. 1998 Aug;20(4):427-34. http://dx.doi.org/10.1093/ejo/20.4.427. PMid:9753824. 
20. Marques LS, Ramos-Jorge ML, Rey AC, Armond MC, Oliveira Ruellas AC. Severe root resorption in orthodontic patients treated with the edgewise method: prevalence and predictive factors. Am J Orthod Dentofacial Orthop. 2010 Mar;137(3):384-8. http://dx.doi.org/10.1016/j.ajodo.2008.04.024. PMid:20197177.

21. Carlson DS. Evolving concepts of heredity and genetics in orthodontics. Am J Orthod Dentofacial Orthop. 2015 Dec;148(6):922-38. http://dx.doi.org/10.1016/j.ajodo.2015.09.012. PMid:26672698.

22. Levander E, Bajka R, Malmgren O. Early radiographic diagnosis of apical root resorption during orthodontic treatment: a study of maxillary incisors. Eur J Orthod. 1998 Feb;20(1):57-63. http://dx.doi.org/10.1093/ejo/20.1.57. PMid:9558765.

23. Kook YA, Park S, Sameshima GT. Peg-shaped and small lateral incisors not at higher risk for root resorption. Am J Orthod Dentofacial Orthop. 2003 Mar;123(3):253-8. http://dx.doi.org/10.1067/mod.2003.81. PMid:12637897.

24. Lind V. Short root anomaly. Scand J Dent Res. 1972;80(2):85-93. PMid:4505388.

25. SAS Institute Inc. SAS statistical program, release 9.2. Cary; 2010.

26. Oliveira AG, Consolaro A, Junqueira JLC, Martins-Ortiz MF, Franzolin SOB. Analysis of predictors of root resorption in orthodontic treatment - part II. J Dent Oral Hyg. 2011 Jun;3(6):75-81. http://dx.doi.org/10.5897/JDOH2011.000-3150.

\section{CONFLICTS OF INTERESTS}

The authors declare no conflicts of interest.

\section{*CORRESPONDING AUTHOR}

Viviane Veroni Degan, FHO - Fundação Hermínio Ometto, Departamento de Ortodontia, Av. Dr. Maximiliano Baruti, 500, 13607-339 Araras - SP, Brasil, e-mail: vivianedegan@fho.edu.br; vivianedegan@fho.edu.br

Received: September 26, 2019

Accepted: November 11, 2019 